\title{
DURATION OF DEVELOPMENT AND SURVIVAL OF LARVAE OF COCCINELLA TRANSVERSALIS FED ON ESSENTIAL AND ALTERNATIVE FOODS
}

\author{
NAVODITA MAURICE${ }^{1}$, AHMAD PERVEZ2², ASHWANI KUMAR ${ }^{1}$, \\ P. W. RAMTEKE ${ }^{1}$ \\ ${ }^{1}$ Department of Biological Sciences, Sam Higginbottom Institute of Agriculture, Technology and Sciences, (Formerly Allahabad \\ Agricultural Institute), Deemed-to-be-University, Naini, Allahabad-211007, India \\ ${ }^{2}$ Biocontrol Laboratory, Department of Zoology, Govt. Degree College, Talwari-Tharali, Chamoli-246482, Uttarakhand, India; \\ Phone: 91-1363-277843 \\ *Corresponding author: ahmadpervez@yahoo.com
}

\section{ABSTRACT}

Food in providing essential nutrients for development and sustaining longevity is an important determinant in the survival of organisms. The aphidophagous ladybird beetle Coccinella transversalis is common in the Oriental region and feeds on a wide range of aphids that infest and seriously reduce the yield of agricultural crops. The availability of aphids fluctuates throughout the year, being usually present at the end of July and decreasing at the end of March. In this study C. transversalis was fed on essential (aphids) and alternative foods. The development was fastest with high larval survival when larvae were fed on A. craccivora followed by U. compositae, L. erysimi, A. gossypii, R. maidis, H. setariae, and H. coriandri. The alternative foods used were mealy bugs (coccids), honey, sugar syrup and pollen, however only the former two supported the survival and development.

Keywords: Coccinella transversalis, Aphis craccivora, Lipaphis erysimi, mealy bugs, artificial diet, larval survival

\section{Introduction}

Ladybird beetles are very popular cosmopolitan insects, most of which feed on aphids, mealy bugs, scale insects, white flies, thrips, leafhoppers, mites or other small soft bodied insects (Gautam 1989; Omkar and Pervez 2000). Food specificity has been a long standing and important issue in the ecology of ladybirds (Hodek 1967). Thompson (1951) was the first to suggest that many ladybirds are not generalists but have specific food requirements. Because aphids are abundant for only a short period of time each year aphidophagous ladybirds also consume other types of food. Thus, it is necessary to distinguish between essential and alternative foods.

Food that sustains larval development and oviposition is considered to be essential while those that serve only as a source of energy and prolong survival are categorized as alternative food (Hodek 1996). Aphids are essential food for aphidophagous ladybird beetles. However, they also feed on other arthropods, e.g. Stenorrhyncha (Psyllidae, Aleyrodidae, Coccidae), Acari, Thysanoptera and larvae of Diptera, Coleoptera and Lepidoptera (Kanervo 1940; Hodek 1970, 1973; Singh et al. 1991).

Aphidophagous ladybird beetles are also known to feed on plant matter, such as pollen, nectar and fungal spores (Hemptinne and Desprets 1986; Hemptinne et al. 1988). In recent years the list of aphid species and other foods eaten by ladybird beetles has increased, but most studies on the suitability of different foods are based on feeding experiments under laboratory conditions or field observations of individual ladybirds. It is difficult to decide whether consuming a certain food item is a common oc- currence or not based on a single field observation. Therefore, little is known about the composition of the diet of Coccinella transversalis Fabricius in nature (Triltsch 1999).

Coccinella transversalis is a common polyphagous ladybird beetle in the Oriental region in agricultural fields (Omkar and Bind 1993; Omkar and Srivastava 2003). The main objective of this study was to determine how well this ladybird develops and survives when fed on a range of different aphids, which are available at different times in the season, and on alternative foods when aphids are not available. The sequence of different species of aphids that starts to become available in the field in mid July provided the essential food and when the aphids became scarce in late March the ladybirds were fed four other alternative foods.

\section{Material and Methods}

\section{Stock culture}

Adults of C. transversalis were collected from agricultural fields adjoining Allahabad and used to establish a stock culture in the laboratory. Mating pairs were collected from the stock culture and kept in plastic Petri dishes $(9.0 \times 2.0 \mathrm{~cm})$ at $27 \pm 1{ }^{\circ} \mathrm{C}, 65 \pm 5 \% \mathrm{RH}$ and a $14: 10 \mathrm{LD}$ photoperiod in an Environmental Test Chamber (REMI Instruments). They were fed daily ad libitum on aphids, viz. Aphis craccivora Koch, Aphis gossypii Glover, Hysteroneura setariae (Newstead), Lipaphis erysimi (Kaltenbach) or Uroleucon compositae Theobald infesting twigs of Dolichos lablab L., Lagenaria vulgaris 
Ser., Cynodon dactylon Pers., Raphanus sativus Linnaeus or Carthemus tinctorius L., respectively. Surviving aphids were removed every 24 hours in order to avoid microbial infections. The eggs laid by these pairs were used in the following experiments.

\section{Experimental setup}

The major objective of this study was to determine the development and survival of $C$. transversalis throughout a year when aphids are available and absent, i.e., by feeding them either on a diet of essential prey or alternative prey. Larvae that hatched from the eggs laid by the ladybirds were kept singly in Petri dishes in order to avoid cannibalism. The survival and duration of development was recorded on both types of diets. Eight species of aphids, viz. A. craccivora, A. gossypii, Hysteroneura setariae (Thomas, Rhopalosiphum maidis (Fitch), L. erysimi, A. nerii, Hydraphis coriandri (Das) and U. compositae were the essential prey and were provided in sequence depending on their availability over the period July to March. The four alternative foods were mealybug, $M a-$ conellicoccus hirsutus (Green) from Hibiscus rosa sinensis L., pollen, sugar syrup and honey. This experiment was replicated twenty times. The percent larval survival (i.e., number of pupae formed $\times 100 /$ number of first instars hatched) on each essential and alternative food was also calculated. Two-way ANOVA was done using "food" (essential and alternative food) and "species" (different types of aphids and other foods) as independent variables and developmental period of various life stages as dependent variable on statistical software SAS. The instars died in the course of development were excluded from the analysis.

\section{Results}

The effect of eight aphid species on the development period of $C$. transversalis is presented (Fig. 1). The durations of development of the larval stages of $C$. transversalis were shortest, in the following order, when fed A. craccivora, U. compositae, L. erysimi, A. gossypii, R. maidis, $H$. setariae, and $H$. coriandri. Fourth instar larva had the longest development period compared to other life stages when fed on different aphid species (Fig. 1). Second larval instars did not complete development when fed on $A$. nerii and died before moulting. The larvae completed the development only on mealy bugs and honey compared to the four alternative foods provided with shorter development period on the former food (Fig. 2). Two way ANOVA revealed that the main effect of "food" ( $F=10.33$; $\mathrm{P}<0.001$; d.f. $=8,163)$ and "species" $(\mathrm{F}=4.19 ; \mathrm{P}<0.001$; d.f. $=8,163)$ was significant on first instar duration. The interaction was, however, not $(F=0.21$; N.S. $)$. Similarly, the main effect of "food" $(\mathrm{F}=34.22 ; \mathrm{P}<0.0001$; d.f. $=8$, $145)$ and "species" ( $\mathrm{F}=10.39 ; \mathrm{P}<0.0001 ;$ d.f. $=8,145)$ was significant on second instar duration with insignif-

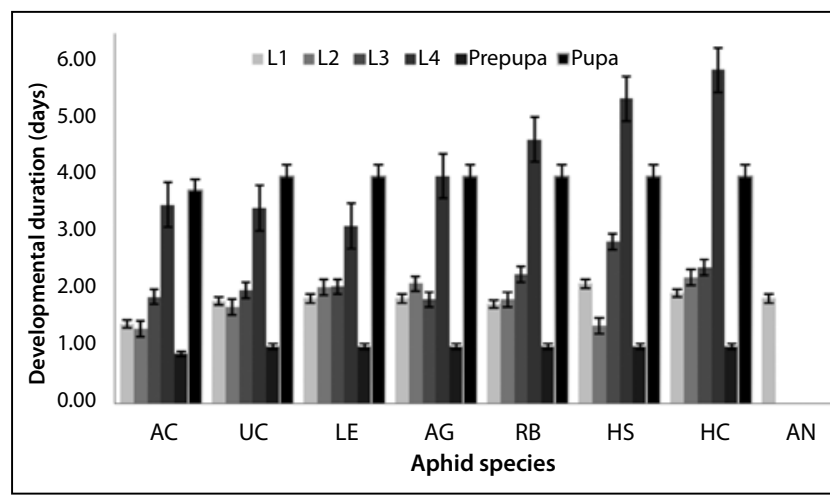

Fig. 1 Duration of developmental stages of Coccinella transversalis fed on different species of aphids.

( $A C=$ A. craccivora, $U C=U$. compositae, $L E=L$. erysimi, $A G=A$. gossypii, $R M=R$. maidis, $H S=H$. setariae, $H C=H$. coriandri and $A N=A$. nerii; $L 1$, $\mathrm{L} 2, \mathrm{~L} 3$ and $\mathrm{L} 4=$ first, second, third, fourth larval instars, respectively). Error bars represent \pm S.E.

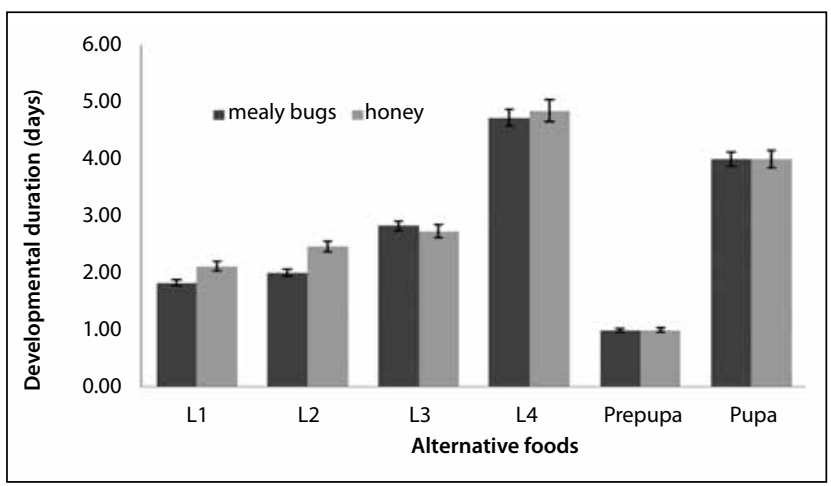

Fig. 2 Duration of larval development of Coccinella transversalis fed on alternative foods.

L1, L2, L3 and L4 are first, second, third and fourth larval instars respectively.

Error bars represent \pm S.E.

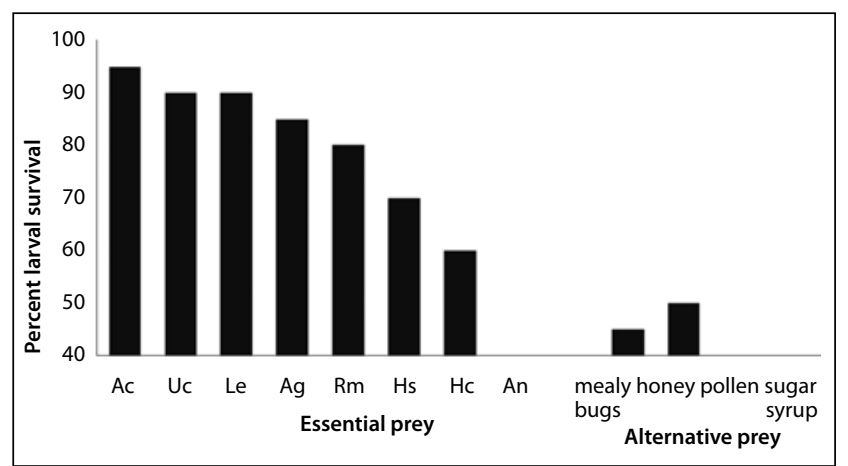

Fig. 3 Percent larval survival of $C$. transversalis when fed on different essential prey and alternative foods.

icant $(\mathrm{F}=0.10$; N.S.) interaction between the two. The main effect of "food" ( $\mathrm{F}=21.873 ; \mathrm{P}<0.001$; d.f. $=8,130)$ and "species" ( $\mathrm{F}=3.94 ; \mathrm{P}<0.01$; d.f. $=8,130)$ was also significant on third instar duration. The interaction was not significant $(F=0.65$; N.S.). Similarly, the main effect of "food" $(\mathrm{F}=4.14 ; \mathrm{P}<0.05 ;$ d.f. $=8,122)$ and "species" $(\mathrm{F}=9.22 ; \mathrm{P}<0.001$; d.f. $=8,122)$ was also significant on fourth instar duration. The interaction between them was 
also significant $(\mathrm{F}=5.28 ; \mathrm{P}<0.05)$. However, the main effects of both "food' and "species" along with interactions were not significant on prepupal (N.S.; d.f. $=8,115$ ) and pupal (N.S.; d.f. $=8,112$ ) durations. The percent larval survival was higher on essential prey compared to alternative prey (Fig. 3 ).

\section{Discussion}

The results of this study indicate that ladybird beetles survive well when aphids are plentiful from mid July to the end of March. Aphids that sustain larval development and oviposition in ladybirds are considered to be essential food from an eco-physiological point of view. Essential food however, varies in quality, which results in different developmental rates, fecundities and survival (Hodek 1993; Hodek and Honěk 1996). Recent results indicate that Harmonia axyridis (Pallas) fed on a diet consisting of a mixture of different species of aphids are fitter than those fed a diet consisting of a single species of aphid (Soares et al. 2004). The duration of development of $C$. transversalis was shortest when the larvae were fed on A. craccivora, U. compositae, L. erysimi and A. gossypii. Similar findings are reported for Coelophora biplagiata (Swartz) but the order of suitability of the aphids is reversed in the case of Micraspis discolor ( $\mathrm{Fa}$ bricius) (Omkar et al. 2005; Ashraf et al. 2010). However, the duration of development was more prolonged when the ladybird larvae were fed on $R$. maidis, $H$. setariae and $H$. coriandri. This may be attributed to the fact that although some species of aphids appear to be readily accepted as food by larvae and adults eating them can significantly reduce their fitness. In addition, though many aphid species appear to be suitable prey they are difficult to catch or wax and glandular hairs on the surface of plants impede the movement of ladybirds, especially the larvae, making it more difficult for them to catch the aphids.

There was a significant main effect of the "food" in terms of essential and alternative foods on all the instar durations. This clearly reveals that essential food in the form of preferred aphids enabled expedite larval development. The main effects of the "food" were not significant on the prepupal and pupal developments. It is likely that the nutrients from the essential food also help to expedite the pupal development period (Pervez and Omkar 2004), however, present study finds the possible role of nutrients from the essential food to be insignificant in affecting pupal duration. The main effect of "species", i.e., different types of aphids and other alternative foods was also significant on all the four instar durations. This reveals that aphid species affected differently on the instar moulting. The aphids with possibly better nutritive value like $A$. craccivora, $U$. compositae and $L$. erysimi expedited the instar moulting than the other ones. This might be the reason of high incidence of $C$. transversalis in the agricultural fields having heavy infestations of A. craccivora and L. erysimi (Pervez, personal observation).

All of the first instar larvae of $C$. transversalis fed A. nerii failed to moult to the second instar and died. This may be due to the fact that $A$. nerii sequesters toxins from plants. Evidence from predation exclusion manipulations in the field is consistent with a trade-off between direct and indirect defence (Mohl and Heimpel 2010). There is increasing evidence that plant defence can have ecological costs when they disrupt interactions with potential mutualists. This may be particularly relevant when it is planned to use both arthropod biological control and host plant resistance for controlling insect pests in agro-ecosystems. Energy derived from prey is used by adult predators to fuel their searching behaviour and reproduction. The ladybird larvae fed mealy bugs and honey survived but those fed sugar syrup and pollen died. The results of numerous studies on the response of aphidophagous ladybirds to non-aphid prey are confusing because one would expect them to develop and/or oviposit eggs only when they have located a patch of nursery prey. Adults of Coccinella septempunctata L. and Coccinella transversoguttata Faldermann increase in body weight but fail to produce eggs when fed on weevil larvae (Richards and Evans 1998). Mealy bugs and honey supported slow larval development, which may be because the body covering of mealy bugs is unpalatable and honey, although rich in sugars is a poor source of protein.

Pollen is an unsuitable food because its surface structure causes it to clump and accumulate on the cuticle of larvae, which resulted in all of them dying in the first instar of desiccation, as is reported for Coleomegilla maculata DeGeer (Michaud and Grant 2005). None of the larvae fed sugar syrup developed or grew, which clearly indicates that it is an unsuitable alternative food, possibly because it lacks fat and proteins. The results indicate that the duration of development of the larvae of $C$. transversalis is shorter when fed A. craccivora, U. compositae, L. erysimi, A. gossypii than $R$. maidis, $H$. setariae and $H$. coriandri and when aphids are not available mealy bugs and honey appear to be better alternative foods than pollen and sugar syrup.

\section{Acknowledgements}

AP thanks the Department of Science and Technology for providing assistance through the SERC Young Scientist Research Project (SR/FT/L-093/2008) and a travel grant (SR/ITS/02170/2010-2011 Dated 24/8/2010). NM, AK and PWR thank the Vice Chancellor, Prof. R. B. Lal; Director (Research), Dr. D. M. Dennis, and Head, Department of Biological Sciences, Sam Higginbottom Institute of Agriculture, Technology and Sciences, (Deemedto-be University), Formerly AAIDU, Allahabad, India, for providing laboratory facilities. 


\section{REFERENCES}

Ashraf M, Ishtiaq M, Mehmood T (2010) A study on laboratory rearing of ladybird beetle (Coccinella septempunctata) to observe its fecundity and longevity on natural and artificial diets. Int J Biol 2: 1.

Gautam RD (1989) Influence of different hosts on the adults of Menochilus sexmaculatus (Fab). J Biol Control 3: 90-92.

Hemptinne J-L, Desprets A (1986) Pollen as a spring food for Adalia bipunctata. In: Hodek I, (ed) Ecology of Aphidophaga, Academia, Prague, pp 29-35.

Hemptinne J-L, Naisse J, Os S (1988) Glimpse of the life history of Propylea quatuordecimpunctata (L.) (Col.: Coccinellidae). Med Fac Landbouww Rijksuniv Gent 53: 1175-1182.

Hodek I (1967) Bionomics and ecology of predaceous Coccinellidae. Ann Rev Ent 12: 79-104.

Hodek I (1970) Coccinellids and the modern pest management. Bioscience 20: 543-552.

Hodek I (1973) Biology of Coccinellidae. Academia Publishing House and Dr W. Junk N. V. Publishers, The Hague.

Hodek I (1996) Food relationships. In: Hodek I, Honek A (eds.) Ecology of Coccinellidae. Kluwer Academic Publishers, Dordrecht Boston London, pp 143-238.

Hodek I, Honěk A (1996) Ecology of Coccinellidae. Kluwer Academic Publishers, Dordrecht.

Kanervo V (1940) Beobachtungen und Versuche zur Ermittlung der Nahrung einiger coccinelliden. Ann Ent Fenn 6: 89-110.

Michaud JP, Grant AK (2005) Suitability of pollen sources for development and reproduction of Coleomegilla maculata (Coleoptera: Coccinellidae) under stimulated drought conditions. Biol Control 32: 363-370.
Mohl EK, Heimpel GE (2010) A potential trade-off between direct and indirect defences in plants. Proc Ecol Aphidophaga 11: 44.

Omkar, Bind RB (1993) Records of aphid-natural enemies of Uttar Pradesh-II. The coccinellids. J Adv Zool 14: 96-99.

Omkar, Pervez A (2000) Biodiversity in predaceous coccinellids (Coleoptera: Coccinellidae) in India - A review. J Aphidol 14: 41-66.

Omkar, Pervez A, Singh SK (2005) Development and immature survival of two aphidophagous ladybirds, Coelophora biplagiata and Micraspis discolor. Insect Sci 12: 375-379.

Omkar, Srivastava S (2003) Comparative prey consumption and searching efficiency of ladybeetles, Coccinella septempunctata Linnaeus and Coccinella transversalis Fabricius for different aphid species. J Biol Control 17: 35-41.

Pervez A, Omkar (2004) Prey dependent life attributes of an aphidophagous ladybird beetle, Propylea dissecta (Mulsant). Biocontrol Sci Tech 14: 385-396.

Richards DR, Evans EW (1998) Reproductive responses of aphidophagous lady beetles (Coleoptera: Coccinellidae) to non-aphid diets: An example from alfalfa. Ann Ent Soc Am 91: 632-640.

Singh TVK, Singh KM, Singh RN (1991) Influence of intercropping: III. Natural enemy complex in groundnut. Ind J Ent 53: 333-368.

Soares AO, Coderre D, Schanderl H (2004) Influence of prey quality on the fitness of two phenotypes of Harmonia axyridis adults. Ent Exp Appl 114: 227-232.

Thompson WR (1951) The specificity of host relations in predaceous insects. Can Ent 83: 262-269.

Triltsch H (1999) Food remains in the guts of Coccinella septempunctata (Coleoptera: Coccinellidae) adults and larvae. Eur J Ent 96: 355-364. 